\title{
Sensitivity of Monilinia oxycocci to Fenbuconazole and Propiconazole in vitro and Control of Cranberry Cottonball in the Field
}

\author{
P. S. McManus, V. M. Best, R. P. Voland, and B. L. Leininger, Department of Plant Pathology, University of Wis- \\ consin, Madison 53706
}

\begin{abstract}
McManus, P. S., Best, V. M., Voland, R. P., and Leininger, B. L. 1999. Sensitivity of Monilinia oxycocci to fenbuconazole and propiconazole in vitro and control of cranberry cottonball in the field. Plant Dis. 83:445-450.

The efficacy of fungicides in controlling cottonball disease of cranberry was tested during 1996 to 1998 at three locations in Wisconsin. For some fungicides, the efficacy of four applications, two each during shoot elongation and bloom, was compared with two applications during bloom only. Spraying twice during bloom was as effective in controlling secondary infection as spraying twice during shoot elongation plus twice during bloom. Azoxystrobin, cyprodinil, and propiconazole were equally effective. None of the treatments affected yield, fruit retention, or berry weight compared with the controls. Sensitivity of $M$. oxycocci, the cottonball pathogen, to fenbuconazole and propiconazole was tested in vitro by comparing the distributions of $\mathrm{ED}_{50}$ values of populations collected from three sites that differed in previous exposure to fungicides. Median $\mathrm{ED}_{50}$ values for fenbuconazole were significantly greater at sites where sterol demethylation inhibitor fungicides had been used compared with a site where fungicides had never been used, but median $\mathrm{ED}_{50}$ values for propiconazole did not differ among sites. There was no correlation between the sensitivities to fenbuconazole and propiconazole. The data will form the basis of recommendations aimed at delaying the onset of fungicide resistance and will provide a baseline for monitoring resistance to fenbuconazole and propiconazole in populations of $M$. oxycocci in the future.
\end{abstract}

Cranberry (Vaccinium macrocarpon Aiton) is the most important fruit crop in Wisconsin, with approximately 5,600 ha in production and a farm gate value of about $\$ 120$ million in 1997. Cottonball, caused by the fungus Monilinia oxycocci (Woronin) Honey, occurs in all of the cranberrygrowing regions of the state and has increased in importance over the last 25 years (9). The reasons for this are not known, but the disease is now an insidious and significant threat to the industry. About 20 to $25 \%$ of the crop is treated during the growing season with up to four applications of fungicides, the only demonstrated means of controlling cottonball. Left unchecked, disease incidence can be greater than $40 \%$ (8).

M. oxycocci overwinters as pseudosclerotia beneath the dense cranberry canopy. In midspring, apothecia emerge from the pseudosclerotia and release ascospores at about the time that shoots resume growth. Primary infection occurs on elongating, succulent shoots. About 3 to 4 weeks later, coinciding with bloom, conidia are borne on ectostromata at the termini of infected

Corresponding author: P. S. McManus
E-mail: psm@plantpath.wisc.edu

Accepted for publication 9 February 1999.

Publication no. D-1999-0308-01R

(C) 1999 The American Phytopathological Society shoots. Conidia are carried by wind and/or insects to flowers, whereupon secondary infection occurs. When the fungus reaches the ovary, it forms a cottonlike mycelium within the locules of the developing fruit. By harvest, pseudosclerotia develop in 25 to $50 \%$ of the infected fruit $(9,18,19)$. Secondary infection causes economic losses $(8,21)$, and field research suggests that control is more efficient when this stage of the disease cycle is targeted $(8,15)$. However, current control recommendations include two fungicide applications aimed at primary infection of elongating shoots plus two applications aimed at secondary infection of flowers.

Triforine, a sterol demethylation inhibitor (DMI) fungicide, had been used for control of cottonball since 1982. However, production of triforine was discontinued in the early 1990s, and during 1996 to 1998 , propiconazole, also a DMI, was used under a Section 18 emergency exemption. A third DMI, fenbuconazole, is effective against cottonball (8) and some other fruit rot diseases (16), and may become registered on cranberry in the future. Other classes of fungicides have been or are currently permitted on cranberry (14), but these have been less effective in controlling cottonball than the DMIs (8). On most cranberry marshes where cottonball occurs, it is the only economically important disease, and the DMIs have been used exclusively for many years. Although there have not been reports of failure of DMIs to control cot- tonball, the use pattern of DMIs is risky in light of the growing number of reports of resistance to members of this valuable group of fungicides $(1,3,6,12,17,20,22,23,25)$.

We are developing an integrated, sustainable program for managing cottonball $(10,15)$. Although cultural and biological methods of control are under study (10), their implementation is not imminent. Thus, our immediate goals are to delay the onset of fungicide resistance and to establish criteria for monitoring populations of $M$. oxycocci for resistance to fungicides. In this study, we tested the effect of eliminating fungicide applications during shoot elongation and the effect of non-DMI fungicides on disease incidence, yield, and selected yield components. In addition to results from field trials, we report the in vitro sensitivities of populations of $M$. oxycocci with different histories of exposure to DMI fungicides.

\section{MATERIALS AND METHODS}

Field plot experimental design. Plots were established in early May at commercial cranberry marshes in central and northern Wisconsin during 1996, 1997, and 1998. Growers at these sites had reported moderate to severe cottonball in recent years. In 1996 and 1997, plots were established in beds of the cultivars Ben Lear and Searles in central (site C) and north-central (site NC) Wisconsin, respectively. Individual replicate plots were $1.5 \times 1.5 \mathrm{~m}$ with 0.5-m untreated borders between plots. In 1996 at site NC, the entire experiment was performed in an area of the bed to which $1.5 \mathrm{~cm}$ of sand had been applied during the previous winter, and in an area that had received no additional sand. In 1998, plots were established in a bed of Searles in northwestern Wisconsin (site NW). Individual replicate plots were $1.5 \times 2.0 \mathrm{~m}$ with $1.0-\mathrm{m}$ borders between plots. For all plots in all years, treatments were arranged in a randomized complete block design with eight treatment replications.

Treatments and application in relation to host phenology. Treatments differed in the fungicide applied or in the number and timing of applications relative to host phenology. For some fungicides, the efficacy of four applications, two each during shoot elongation and bloom, was compared with two applications during bloom. Applications during shoot elongation were made when approximately $50 \%$ of shoots had at least $1 \mathrm{~cm}$ of new growth 
and 7 to 12 days later. This corresponded to 30 May and 11 June at site $C$ in 1996; 4 and 13 June at site NC in 1996; 3 and 12 June at site $C$ in 1997; 9 and 18 June at site $\mathrm{NC}$ in 1997; and 22 and 29 May at site NW in 1998. Applications during bloom were made when 10 to $20 \%$ of flowers had opened and 7 to 10 days later. This corresponded to 1 and 11 July at site C in 1996; 9 and 18 July at site NC in 1996; 26 June and 3 July at site C in 1997; 5 and 12 July at site NC in 1997; and 23 and 30 June at site NW in 1998. Fungicides included the DMI fungicides fenbuconazole plus adjuvant (Indar 75 WP plus Latron B-1956, Rohm and Haas Corp., Philadelphia, PA) and propiconazole (Orbit 3.6 E, Novartis Corp., Greensboro, NC); an anilinopyrimidine fungicide, cyprodinil (Vangard 75 WP, Novartis Corp.); and a strobilurin fungicide, azoxystrobin (ICIA5504 2.08 F, Zeneca Ag Products, Wilmington, DE). Fungicides were applied in the equivalent of 468 (in 1996 and 1997) or 702 (in 1998) liters of water per ha with a $\mathrm{CO}_{2}$-powered, hand-held boom sprayer (TeeJet 8002VS flat nozzles, R \& D Sprayers Inc., Opelousas, LA). Growers applied fertilizers and insecticides but no fungicides to the portions of the beds in which tests were conducted. An exception was at site $\mathrm{C}$ in 1996 and 1997, where the grower made three applications of copper hydroxide after fruit set to protect the developing fruit from diseases other than cottonball. Copper hydroxide, even when applied during shoot elongation and bloom, does not affect cottonball incidence (8).

Disease and yield data collection. Primary infection of shoots was assessed in late June or early July of each year when symptoms were estimated to be maximal. This usually corresponded with the time of the first bloom spray or up to 5 days later. In 1996, the number of symptomatic shoot termini in three arbitrarily selected $113 \mathrm{~cm}^{2}$ circular areas of each plot was determined. For each plot, the three values were summed to give a single primary infection incidence per $339 \mathrm{~cm}^{2}$ area. In 1997, the number of symptomatic shoots in four arbitrarily selected $270 \mathrm{~cm}^{2}$ circular areas of each plot was determined. For each plot, the four values were summed to give a single primary infection incidence per $1,080 \mathrm{~cm}^{2}$ area. The total number of shoots was not determined. In 1998, primary infection was nearly nonexistent, and data were not collected.

Secondary infection was assessed during middle to late September of each year, no earlier than 10 days prior to commercial harvest. The total area sampled varied among years and sites to account for variation in yield and disease incidence; if yield or disease incidence appeared low, then a greater area was sampled. Plots were sampled by collecting all fruit from two to four arbitrarily selected $270 \mathrm{~cm}^{2}$ circular areas within each plot. Subsamples were com- bined into one sample per plot. The number of $270 \mathrm{~cm}^{2}$ subsamples per plot was two at site C in 1996, three at site NC in 1996, three at sites C and NC in 1997, and four at site NW in 1998. In the laboratory, samples were sorted into three categories based on external symptoms and presence of mycelium or pseudosclerotia of $M$. oxycocci in fruit locules: (i) berries that were asymptomatic and marketable, (ii) berries with signs and symptoms of cottonball, and (iii) berries that were soft or unmarketable for reasons other than cottonball. The following data were obtained: percentage of berries with cottonball (i.e., incidence of secondary infection), yield (i.e., weight of marketable berries), and average berry weight of marketable berries.

Shoot samples for evaluation of fruit retention were collected at the time fruit samples for evaluation of secondary infection were collected. Shoots from three arbitrarily selected areas in each plot were pooled into a single sample per plot. The number of floral shoots collected from each plot ranged from 9 to 100 but was usually in the range of 25 to 50 . In the laboratory, floral shoots (i.e., those with fruit or pedicels on the current season's growth) were separated from vegetative shoots. Flower pedicels were used as a measure of flowers produced $(4,5)$, mature berries were counted, and percent fruit retention (ratio of the number of mature berries per number of flowers [7]) was calculated.

Sampling locations and fungal isolations. Shoots and berries with signs and symptoms of cottonball were collected in 1996 from three sites in central Wisconsin with various histories of exposure to fungicides. Site 1, two adjacent beds of the cultivar McFarlin located in Jackson County, had never been exposed to fungicides. Site 2, two adjacent beds of the cultivars Stevens and Ben Lear located in northeastern Monroe County, had received two to four applications of triforine every year from 1989 to 1995 and four applications of propiconazole in 1996. These were the only fungicides that had been applied since the beds were established in 1987. Site 3, a bed of the cultivar Ben Lear located in north-central Monroe County, had received two to four applications of triforine every year from 1982 to 1995 and four applications of propiconazole in 1996. Additionally, up to four applications of other fungicides, such as captafol, chlorothalonil, copper compounds, and mancozeb, were applied each year since the bed was established in the middle 1960s.

M. oxycocci was isolated from surfacedisinfested infected shoots and fruit on potato dextrose agar (PDA) amended with streptomycin sulfate at $100 \mu \mathrm{g} \mathrm{ml}^{-1}$ to inhibit bacterial growth. Although conidia germinated on water agar and PDA, colonies never developed from individual conidia, and obtaining single-conidial isolates was not possible. Therefore, in this study, an isolate was defined as the fungal mycelium that grew from a single infected shoot or fruit and the asexual progeny of that mycelium. Isolates were stored as mycelia under mineral oil at $4^{\circ} \mathrm{C}$ or as mycelia and spores in sterile water at $4^{\circ} \mathrm{C}$.

Fungicide sensitivity in vitro. The sensitivity of each isolate of $M$. oxycocci to fenbuconazole and propiconazole was determined by a modification of the mycelial radial growth assay for DMI fungicides $(1,17,23)$. Fifty and 51 isolates from sites 1 and 2 , respectively, were tested for sensitivity to both fungicides. Forty-six and 52 isolates from site 3 were tested for sensitivity to fenbuconazole and propiconazole, respectively. Fenbuconazole (Indar $75 \mathrm{WP}$ ) was dissolved in acetone and added to PDA for final concentrations of $0,0.002$, $0.004,0.007,0.010,0.015,0.020$, and $0.030 \mu$ a a.i. $\mathrm{ml}^{-1}$. Propiconazole (Orbit 3.6 E) was diluted in xylene and added to PDA for final concentrations of $0,0.005,0.010$, $0.020,0.030,0.040,0.05$, and $0.100 \mu \mathrm{g}$ a.i. $\mathrm{ml}^{-1}$. Unamended control PDA contained acetone or xylene to simulate the solvent concentration of fungicide-amended PDA. Fungal isolates were grown on unamended PDA for 14 to 20 days, after which mycelia and spores were homogenized in $1 \mathrm{ml}$ of sterile water. Three 20- $\mu$ l aliquots of each fungal suspension were transferred to each dish of PDA in the fungicide concentration series. After 2 weeks of incubation at $20^{\circ} \mathrm{C}$ with a $12-\mathrm{h}$ photoperiod provided by fluorescent lights, the diameter of each fungal colony was measured and adjusted by subtracting $5 \mathrm{~mm}$, the approximate diameter of the 20- $\mu$ l aliquot of fungal suspension. The three adjusted values per dish were averaged for a mean colony diameter for each isolate on each fungicide concentration. Relative growth of each isolate was calculated as the mean colony diameter on each fungicide concentration divided by the mean colony diameter on solvent-amended control PDA.

Statistical analyses. Disease incidence, yield, and yield components were analyzed by analyses of variance (ANOVAs) with MINITAB (Release 10 Extra) statistical software (Minitab, Inc., State College, PA). Means were separated by Fisher's protected least significant difference (LSD) with $P=0.05$. Primary infection data were transformed by calculating $\ln (X+1)$, where $X$ is the number of blighted shoot termini, before analysis and means separation. Data are reported as actual number of blighted shoot termini. Secondary infection and fruit retention proportions were transformed by calculating $\arcsin \sqrt{ } X$, where $X$ is the proportion of fruit with cottonball or the proportion of fruit retained before analysis and means separation. Data are reported as actual percentages.

Linear regression of relative growth on the $\log _{10}$-transformed fungicide concentration was used to estimate $\mathrm{ED}_{50}$ values for 
Table 1. Effects of fungicides and spray schedule on infection of cranberry by Monilinia oxycocci and on yield and selected yield components ${ }^{\mathrm{q}}$

\begin{tabular}{|c|c|c|c|c|c|c|c|}
\hline \multirow[b]{2}{*}{$\begin{array}{l}\text { Year - site }^{r} \\
\text { Treatment (g a.i./ha) }\end{array}$} & \multicolumn{2}{|c|}{ Number of sprays ${ }^{s}$} & \multirow{2}{*}{$\begin{array}{c}\text { Primary } \\
\text { infection } \\
(\text { no. })^{t}\end{array}$} & \multirow{2}{*}{$\begin{array}{c}\text { Secondary } \\
\text { infection } \\
(\%)^{\mathbf{u}}\end{array}$} & \multirow[b]{2}{*}{ Yield $(\mathbf{g})^{\mathbf{v}}$} & \multirow[b]{2}{*}{$\begin{array}{l}\text { Berry weight } \\
(\mathrm{g})^{\mathrm{w}}\end{array}$} & \multirow[b]{2}{*}{$\begin{array}{c}\text { Fruit } \\
\text { retention }(\%)^{\mathrm{x}}\end{array}$} \\
\hline & $\begin{array}{c}\text { Shoot } \\
\text { elongation }\end{array}$ & Bloom & & & & & \\
\hline \multicolumn{8}{|l|}{$1996-\mathrm{C}$} \\
\hline Propiconazole (189) & 2 & 2 & $0.13 \mathrm{a}^{\mathrm{y}}$ & $1.9 \mathrm{ab}$ & 203 & $0.90 \mathrm{bc}$ & 41 \\
\hline Propiconazole (189) & 0 & 2 & $1.38 \mathrm{bc}$ & $1.8 \mathrm{a}$ & 218 & $0.84 \mathrm{a}$ & 51 \\
\hline Cyprodinil (555) & 2 & 2 & $0.63 \mathrm{ab}$ & $1.8 \mathrm{a}$ & 243 & $0.94 \mathrm{c}$ & 50 \\
\hline Propiconazole(126) + cyprodinil(277) & 2 & 2 & $0.25 \mathrm{a}$ & $2.0 \mathrm{ab}$ & 233 & $0.88 \mathrm{ab}$ & 45 \\
\hline Propiconazole(126) + cyprodinil(277) & 0 & 2 & $2.50 \mathrm{c}$ & $4.5 \mathrm{~b}$ & 303 & $0.90 \mathrm{bc}$ & 49 \\
\hline Control & 0 & 0 & $1.75 \mathrm{bc}$ & $11.4 \mathrm{c}$ & 213 & $0.92 \mathrm{bc}$ & 45 \\
\hline$P^{\mathrm{z}}$ & & & 0.015 & 0.000 & 0.277 & 0.037 & 0.476 \\
\hline \multicolumn{8}{|l|}{1996 - NC (sand) } \\
\hline Propiconazole (189) & 2 & 2 & 0.88 & $7.3 \mathrm{a}$ & 66 & 1.01 & 36 \\
\hline Propiconazole (189) & 0 & 2 & 5.25 & $11.5 \mathrm{a}$ & 52 & 0.94 & 42 \\
\hline Cyprodinil (555) & 2 & 2 & 1.75 & $7.6 \mathrm{a}$ & 61 & 0.98 & 43 \\
\hline Propiconazole(126) + cyprodinil(277) & 2 & 2 & 1.13 & $8.7 \mathrm{a}$ & 73 & 1.04 & 46 \\
\hline Propiconazole(126) + cyprodinil(277) & 0 & 2 & 3.00 & $9.9 \mathrm{a}$ & 54 & 0.97 & 46 \\
\hline Control & 0 & 0 & 1.75 & $22.8 \mathrm{~b}$ & 57 & 0.93 & 47 \\
\hline$P$ & & & 0.062 & 0.014 & 0.140 & 0.321 & 0.610 \\
\hline \multicolumn{8}{|l|}{1996 - NC (no sand) } \\
\hline Propiconazole (189) & 2 & 2 & 0.75 & $5.6 \mathrm{a}$ & 64 & 1.00 & 46 \\
\hline Propiconazole (189) & 0 & 2 & 1.63 & $6.2 \mathrm{a}$ & 72 & 0.99 & 42 \\
\hline Cyprodinil (555) & 2 & 2 & 0.63 & $5.4 \mathrm{a}$ & 53 & 1.11 & 35 \\
\hline Propiconazole(126) + cyprodinil(277) & 2 & 2 & 0.13 & $6.0 \mathrm{a}$ & 58 & 1.03 & 40 \\
\hline Propiconazole(126) + cyprodinil(277) & 0 & 2 & 2.00 & $7.7 \mathrm{a}$ & 48 & 1.05 & 38 \\
\hline Control & 0 & 0 & 1.13 & $16.6 \mathrm{~b}$ & 67 & 1.03 & 41 \\
\hline$P$ & & & 0.072 & 0.000 & 0.148 & 0.279 & 0.604 \\
\hline \multicolumn{8}{|l|}{1997 - C } \\
\hline Propiconazole (126) & 2 & 2 & 0.00 & $0.03 \mathrm{a}$ & 215 & 1.11 & 42 \\
\hline Propiconazole (126) & 0 & 2 & 0.62 & $0.30 \mathrm{a}$ & 206 & 1.06 & 49 \\
\hline Cyprodinil (555) & 2 & 2 & 0.25 & $0.29 \mathrm{a}$ & 201 & 1.06 & 48 \\
\hline Propiconazole(126) + cyprodinil(277) & 0 & 2 & 0.25 & $0.12 \mathrm{a}$ & 206 & 1.05 & 48 \\
\hline Azoxystrobin (281) & 2 & 2 & 0.00 & $0.21 \mathrm{a}$ & 216 & 1.09 & 47 \\
\hline Azoxystrobin (281) & 0 & 2 & 0.13 & $0.16 \mathrm{a}$ & 220 & 1.08 & 52 \\
\hline Fenbuconazole (105) & 2 & 2 & 0.00 & $0.05 \mathrm{a}$ & 205 & 1.10 & 48 \\
\hline Control & 0 & 0 & 0.75 & $1.14 \mathrm{~b}$ & 215 & 1.09 & 46 \\
\hline$P$ & & & 0.092 & 0.043 & 0.299 & 0.721 & 0.248 \\
\hline \multicolumn{8}{|l|}{$1997-\mathrm{NC}$} \\
\hline Propiconazole (189) & 2 & 2 & $0.8 \mathrm{a}$ & $1.08 \mathrm{a}$ & 159 & 1.19 & 43 \\
\hline Propiconazole (189) & 0 & 2 & $8.7 \mathrm{bc}$ & $0.92 \mathrm{a}$ & 172 & 1.18 & 41 \\
\hline Cyprodinil (555) & 2 & 2 & $1.3 \mathrm{a}$ & $1.28 \mathrm{a}$ & 150 & 1.17 & 47 \\
\hline Propiconazole(126) + cyprodinil(277) & 0 & 2 & $10.8 \mathrm{c}$ & $2.17 \mathrm{a}$ & 146 & 1.22 & 41 \\
\hline Azoxystrobin (281) & 2 & 2 & $5.4 \mathrm{ab}$ & $1.38 \mathrm{a}$ & 180 & 1.20 & 40 \\
\hline Azoxystrobin (281) & 0 & 2 & $9.6 \mathrm{bc}$ & $1.43 \mathrm{a}$ & 142 & 1.24 & 41 \\
\hline Control & 0 & 0 & $13.8 \mathrm{c}$ & $6.43 \mathrm{~b}$ & 143 & 1.19 & 42 \\
\hline$P$ & & & 0.000 & 0.000 & 0.491 & 0.476 & 0.721 \\
\hline \multicolumn{8}{|l|}{1998 - NW } \\
\hline Propiconazole (189) & 2 & 2 & $\ldots$ & $0.22 \mathrm{a}$ & 55 & 1.12 & 74 \\
\hline Propiconazole (189) & 0 & 2 & $\ldots$ & $0.09 \mathrm{a}$ & 72 & 1.20 & 64 \\
\hline Azoxystrobin (281) & 2 & 2 & $\ldots$ & $0.00 \mathrm{a}$ & 65 & 1.19 & 71 \\
\hline Azoxystrobin (281) & 0 & 2 & $\ldots$ & $0.09 \mathrm{a}$ & 65 & 1.14 & 71 \\
\hline Fenbuconazole (105) & 2 & 2 & $\ldots$ & $0.31 \mathrm{a}$ & 106 & 1.14 & 68 \\
\hline Fenbuconazole (105) & 0 & 2 & $\ldots$ & $0.25 \mathrm{a}$ & 57 & 1.17 & 75 \\
\hline Control & 0 & 0 & $\ldots$ & $0.99 \mathrm{~b}$ & 62 & 1.20 & 74 \\
\hline$P$ & & & & 0.024 & 0.469 & 0.503 & 0.580 \\
\hline
\end{tabular}

q Fungicides were applied to eight replicate plots per treatment in a randomized complete block design.

${ }^{\mathrm{r}}$ Sites were cranberry beds on commercial marshes in central (C), north-central (NC), and northwestern (NW) Wisconsin. Cultivars were Ben Lear at site $\mathrm{C}$ and Searles at sites NC and NW.

${ }^{\mathrm{s}}$ Applications during shoot elongation were made when approximately $50 \%$ of shoots had at least $1 \mathrm{~cm}$ of new growth and 7 to 12 days later. Applications during bloom were made when 10 to $20 \%$ of flowers had opened and 7 to 10 days later.

${ }^{t}$ Number of infected shoot termini in three $113 \mathrm{~cm}^{2}$ circular areas (1996) or four $270 \mathrm{~cm}^{2}$ circular areas (1997) of each plot were summed to give a single primary infection incidence per $339 \mathrm{~cm}^{2}(1996)$ or $1,080 \mathrm{~cm}^{2}$ (1997) area per plot. In 1998, primary infection was nearly nonexistent and data were not collected. Data were transformed by $\ln (X+1)$ for analysis and means separation.

" Number of infected berries per total number of berries in two to four $270 \mathrm{~cm}^{2}$ circular areas within each plot. Subsamples were combined into one sample per plot. The number of $270 \mathrm{~cm}^{2}$ subsamples per plot was: two at site C in 1996, three at site NC in 1996, three at sites C and NC in 1997, and four at site NW in 1998. Data were transformed by calculating $\arcsin \sqrt{ }$ for analysis and means separation.

${ }^{v}$ Mean weight of marketable berries collected from a $540 \mathrm{~cm}^{2}$ area within each plot. When an area greater than $540 \mathrm{~cm}^{2}$ was sampled (see footnote u), values were standardized to weight per $540 \mathrm{~cm}^{2}$.

${ }^{\mathrm{w}}$ Weight per individual marketable berry.

${ }^{x}$ Number of berries per number of pedicels $\times 100$ on 9 to 100 floral shoots per plot. Proportions were transformed by calculating arcsin $\sqrt{ }$ for analysis and means separation.

y Means within columns for each year $\times$ site followed by the same letter are not significantly different (Fisher's protected least significant difference test, $P=0.05$ ).

${ }^{\mathrm{z}}$ Significance of $F$ statistics for treatments from analysis of variance. 
each isolate. Preliminary analyses determined that the frequency distributions of $\mathrm{ED}_{50}$ values for the three sites were neither normal nor consistently lognormal; therefore, they were compared using the NPAR1WAY procedure in SAS version 6.12 (SAS Institute, Cary, NC) to perform the Kruskal-Wallis test (chi-square approximation [24]). This procedure ranked the $\mathrm{ED}_{50}$ values of all 147 isolates tested on fenbuconazole and all 153 isolates tested on propiconazole and then compared the rank sums for each of the three sites. Rank values were assigned so that rank 1 was the smallest $\mathrm{ED}_{50}$ value. Therefore, the largest rank sum was associated with the site having the largest $\mathrm{ED}_{50}$ values. Mean scores were calculated by dividing each rank sum by the number of isolates associ- ated with it to account for differences in the number of isolates tested from different sites. Resistance factors were calculated as the ratio of the maximum $\mathrm{ED}_{50}$ value to the median $\mathrm{ED}_{50}$ value for each sample. Pearson correlation coefficients were calculated to determine the relationship between sensitivity to fenbuconazole and sensitivity to propiconazole for isolates from site 1 , the site with no history of DMI exposure prior to 1997 (i.e., baseline), and for all isolates from all sites combined.

\section{RESULTS}

Field studies. Fungicide treatments during shoot elongation generally reduced the incidence of primary infection compared with unsprayed plots, but statistically significant differences were detected only

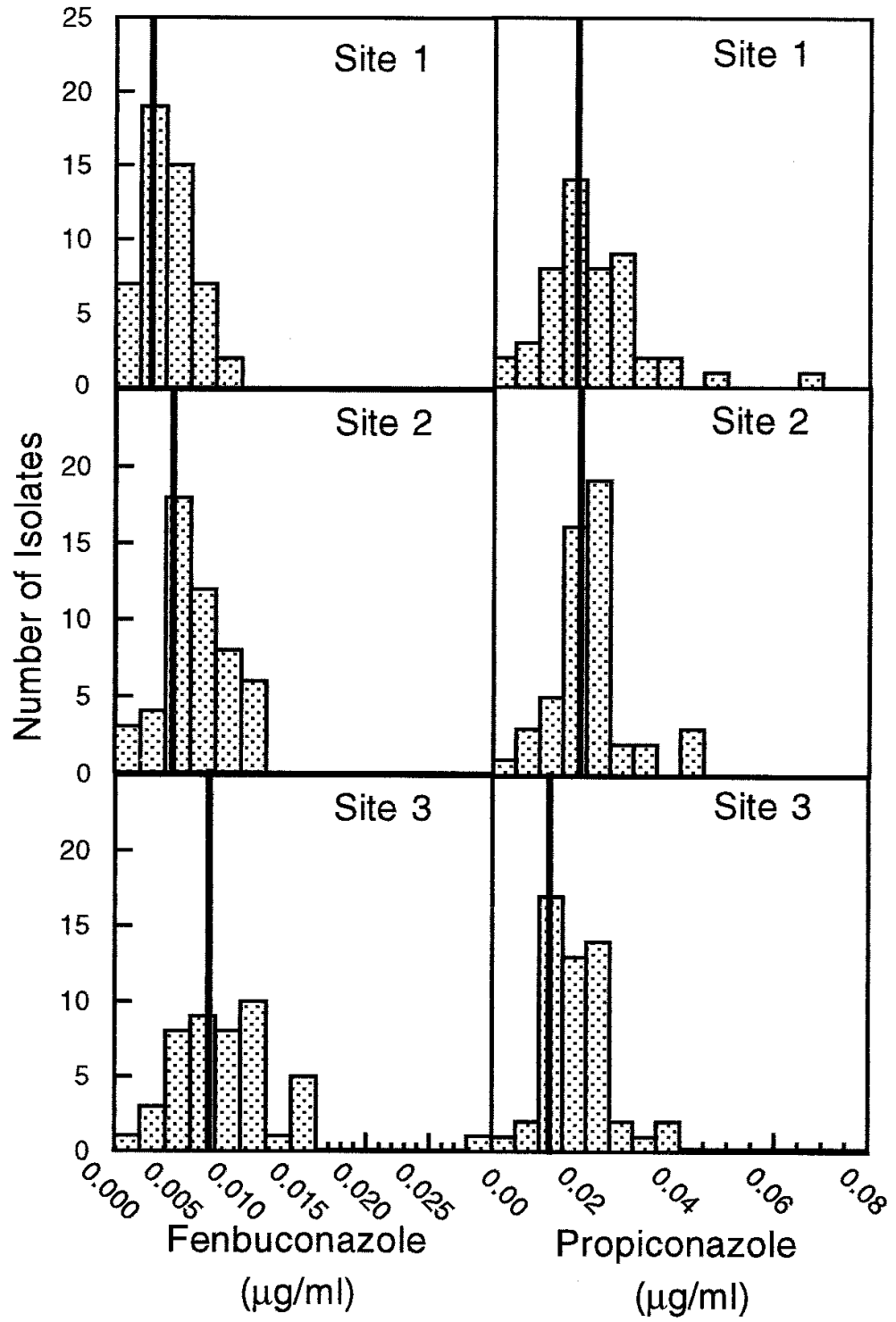

Fig. 1. Frequency distributions of $\mathrm{ED}_{50}$ values to fenbuconazole and propiconazole for isolates of Monilinia oxycocci from three cranberry marshes in Wisconsin. Site 1 had never been exposed to fungicides. Site 2 had received two to four applications of triforine every year from 1989 to 1995 and four applications of propiconazole in 1996. Site 3 had received two to four applications of triforine every year from 1982 to 1995, four applications of propiconazole in 1996, and up to four applications of broad-spectrum protectant fungicides each year since the bed was planted in the middle 1960s. Bold, vertical lines denote population medians. at site C in 1996 and site $\mathrm{NC}$ in 1997 (Table 1). Disease incidence values in Table 1 are based on different sizes of area sampled; larger areas were sampled when disease incidence or yield was lower. Fungicide treatment during bloom consistently reduced the incidence of secondary infection compared with control plots, with little or no difference in efficacy among the different fungicides or spray schedules. Although disease incidence was low in 1997 and 1998, the trends in data were consistent with data collected in 1996. Spraying twice during bloom was as effective in controlling secondary infection as spraying twice during shoot elongation plus twice during bloom. Yield varied among sites and years (analysis not shown), but none of the treatments affected yield or fruit retention compared with the controls. To facilitate comparison of yield values based on different sizes of areas sampled in different trials, values in Table 1 have been standardized as the weight of marketable berries collected from a 540 $\mathrm{cm}^{2}$ area within each plot. Individual berry weight was significantly lower in the treatment in which propiconazole was applied only during bloom at site $\mathrm{C}$ in 1996, but this result was not observed at the same site in 1997 or in other experiments.

Fungicide sensitivity in vitro. The median $\mathrm{ED}_{50}$ values differed among sites for fenbuconazole but not for propiconazole (Fig. 1 and Table 2). Resistance factors for both fungicides were low for isolates from all sites, indicating an absence of isolates that were highly insensitive relative to population means. $M$. oxycocci was more sensitive to fenbuconazole than to the same concentration of propiconazole. There was no correlation between the sensitivities to fenbuconazole and propiconazole for isolates from site 1 (baseline sensitivities) or for the pooled sample of isolates from all sites.

\section{DISCUSSION}

We demonstrate here the feasibility of controlling cranberry cottonball while implementing two strategies commonly recommended to delay the onset of fungicide resistance: (i) reducing the total number of fungicide applications per season, and (ii) using fungicides with different modes of action. Applying fungicides to cranberry twice during bloom was as effective at controlling cottonball incidence at harvest (i.e., secondary infection) as applying fungicides twice during shoot elongation plus twice during bloom. This result is consistent with a previous study in which applying benomyl or chlorothalonil during bloom resulted in a low incidence of secondary infection despite the failure of these fungicides to reduce primary infection (8). If cottonball levels are low, most growers apply fungicides only once or twice per season, generally during shoot elongation. 
Our data show that at least under low to moderate disease pressure, growers who apply fungicides only once or twice per season to control cottonball should do so during bloom. Furthermore, growers who currently apply fungicides four times per season, as recommended, could eliminate two applications without sacrificing disease control or yield.

The non-DMI fungicides azoxystrobin and cyprodinil, and a mixture of cyprodinil and propiconazole, were as effective as propiconazole in controlling cottonball. Azoxystrobin is also effective against cranberry fruit rot diseases (16). Effective alternatives to the DMIs are critical in developing a fungicide program to offset selection for DMI-resistant strains of $M$. oxycocci. The U.S. Environmental Protection Agency has deemed azoxystrobin and cyprodinil "reduced-risk" based on their relatively favorable mammalian and environmental toxicology profiles, which could expedite the registration of these fungicides and give growers alternatives to the DMIs for controlling cottonball.

Potential side effects of fungicides, such as plant growth regulator activity of DMIs $(2,13)$, phytotoxicity of azoxystrobin on certain cultivars of apple (P. S. McManus, unpublished data), and reduction of cranberry yield associated with chlorothalonil $(7,8)$, prompt concerns when new compounds are tested for disease control. The fact that none of the fungicides tested had a negative impact on yield, fruit retention, or berry weight is important because in years when cottonball disease pressure is low, a slight decrease in yield caused by a fungicide would offset the benefit of disease control. Thus, growers might be discouraged from implementing anti-resistance strategies if it meant using a fungicide that reduced yield. Although fungicides generally reduced the incidence of cottonball, they did not improve yield, fruit retention, or berry weight. By contrast, Jeffers (8) reported moderately higher yields in DMItreated plots compared with control plots. This discrepancy might be explained by the low incidence of secondary infection ( 1 to $23 \%$ ) in control plots in the current study compared with the earlier study (31 to $48 \% ; 8)$. Our data suggest that at least when disease pressure is low, statistically significant reductions in cottonball incidence do not translate into statistically significant increases in yield. However, infected berries are unfit for fresh or processing markets, and fruit-receiving stations assess growers fees to sort out infected berries. Thus, cottonball can result in economic losses to growers even if yield is not significantly reduced.

Establishing the baseline sensitivity distribution of $M$. oxycocci is critical for monitoring the evolution of resistance to the DMI fungicides in populations of this important pathogen. The median $\mathrm{ED}_{50}$ values for propiconazole did not differ significantly among sites with various histories of fungicide use, whereas the $\mathrm{ED}_{50}$ values for fenbuconazole were greater at sites where triforine and propiconazole had been used compared with the baseline site. In the laboratory, there was no relationship between sensitivity of isolates to fenbuconazole and propiconazole. Although various degrees of cross-resistance among DMI fungicides are common for fungal pathogens $(12,17,20,25)$, crossresistance is not absolute $(3,13,22)$. One possible explanation for our results is that the DMI fungicide triforine, which was used for 7 and 14 years at sites 2 and 3, respectively, selected for resistance to fenbuconazole but not propiconazole. Alternatively, populations of $M$. oxycocci may merely be variable in sensitivity to fenbuconazole. In any case, it will be necessary to evaluate the sensitivity of $M$. oxycocci to various DMIs separately rather than assume results with one DMI will apply to others in the class as demonstrated for other pathogens $(12,17)$.

Despite the greater intrinsic activity of fenbuconazole compared with propiconazole, resistance factors were similar regardless of the sample (Table 2) and generally small compared with those reported for baseline populations of other fungal pathogens $(17,23)$. Small resistance factors indicate that highly insensitive individuals are not common in the population of $M$. oxycocci. Research on pesticide resistance has often been in response to crises, and plans for resistance management and monitoring have been implemented after significant economic hardship was suffered by individuals and industry. Fortunately, cranberry growers in Wisconsin have not noticed a decline in performance of the DMIs in the field, and low resistance factors for populations of $M$. oxycocci suggest that resistance to DMIs will evolve relatively slowly. However, the sole reliance on DMI fungicides for 16 years and the lack of chemical or cultural alternatives for controlling cottonball put the cranberry industry in a precarious position. The data reported here will support new fungicide registrations, form the basis of recommendations aimed at delaying the onset of fungicide resistance (e.g., reducing the number of sprays per season), and provide a baseline for monitoring for resistance to fenbuconazole and propiconazole in populations of $M$. oxycocci in the future.

\section{ACKNOWLEDGMENTS}

We thank Habelman Bros. Cranberry Co., Plaza Cranberry Farms, and Northland Cranberries, Inc., for providing field sites; M. Clayton for statistical advice; S. Wraith for technical assistance; and J. Andrews, B. Hudelson, and W. Stevenson for comments on the manuscript. This project was funded by Wisconsin Cranberry Board, Inc., Ocean Spray Cranberries, Inc., Cranberry Institute, and Novartis Corp.

\section{LITERATURE CITED}

1. Braun, P. G., and McRae, K. B. 1992. Composition of a population of Venturia inaequalis resistant to myclobutanil. Can. J. Plant Pathol. 14:215-220.

2. Burden, R. S., Cooke, D. T., and Carter, G. A 1989. Inhibitors of sterol biosynthesis and growth in plants and fungi. Phytochemistry 28:1791-1804.

3. Délye, C., Laigret, F., and Corio-Costet, M.-F. 1997. A mutation in the $14 \alpha$-demethylase gene of Uncinula necator that correlates with resistance to a sterol biosynthesis inhibitor. Appl. Environ. Microbiol. 63:2966-2970.

4. Eaton, G. W., and Kyte, T. R. 1978. Yield component analysis in the cranberry. J. Am. Soc. Hortic. Sci. 103:578-583.

5. Eaton, G. W., and MacPherson, E. A. 1978 Morphological components of yield in cranberry. Hortic. Res. 17:73-82.

6. Golembiewski, R. C., and Vargas, J. M., Jr.,

Table 2. Characteristics of the distributions of $\mathrm{ED}_{50}$ values for fenbuconazole and propiconazole of isolates of Monilinia oxycocci from sites with various histories of fungicide exposure

\begin{tabular}{|c|c|c|c|c|c|c|}
\hline \multirow[b]{2}{*}{ Fungicide } & \multirow[b]{2}{*}{ Location } & \multirow[b]{2}{*}{ No. isolates } & \multicolumn{2}{|c|}{$\mathrm{ED}_{50}$ value $\left(\mu \mathrm{g} \mathrm{ml}^{-1}\right)$} & \multirow[b]{2}{*}{ Mean rank score ${ }^{x}$} & \multirow[b]{2}{*}{ Resistance factor $^{y}$} \\
\hline & & & Range & Median & & \\
\hline \multirow[t]{3}{*}{ Fenbuconazole } & Site 1 & 50 & $0.00011-0.00981$ & 0.00372 & 45.3 & 2.6 \\
\hline & Site 2 & 51 & $0.00063-0.01196$ & 0.00624 & 79.0 & 1.9 \\
\hline & Site 3 & 46 & $0.00115-0.02812$ & 0.00861 & 99.6 & 3.3 \\
\hline$P^{\mathrm{z}}$ & & & & & 0.001 & \\
\hline \multirow[t]{3}{*}{ Propiconazole } & Site 1 & 50 & $0.00151-0.06856$ & 0.01950 & 80.0 & 3.5 \\
\hline & Site 2 & 51 & $0.00207-0.04217$ & 0.02037 & 83.6 & 2.1 \\
\hline & Site 3 & 52 & $0.00439-0.03700$ & 0.01710 & 67.6 & 2.2 \\
\hline$P^{\mathrm{z}}$ & & & & & 0.159 & \\
\hline
\end{tabular}

$\overline{\mathrm{x}}$ Rank sums of $\mathrm{ED}_{50}$ values for each of the three sites were compared by the Kruskal-Wallis test. Mean scores were calculated by dividing each rank sum by the number of isolates to account for differences in the number of isolates tested from each site.

y Ratio of the maximum $\mathrm{ED}_{50}$ to the median $\mathrm{ED}_{50}$.

${ }^{\mathrm{z}} P$ values indicate the significance of the Kruskal-Wallis test. 
Jones, A. L., and Detweiler, A. R. 1995. Detection of demethylation inhibitor (DMI) resistance in Sclerotinia homoeocarpa populations. Plant Dis. 79:491-493.

7. Jeffers, S. N. 1991. Effects of fungicides applied during bloom on yield, yield components, and storage rots of cranberry. Plant Dis. 75:244-250.

8. Jeffers, S. N. 1991. Managing cranberry cottonball caused by Monilinia oxycocci with fungicides. Plant Dis. 75:502-506.

9. Jeffers, S. N., and Sanderson, P. G. 1995. Cottonball. Pages 33-35 in: Compendium of Blueberry and Cranberry Diseases. F. L. Caruso and D. C. Ramsdell, eds. American Phytopathological Society, St. Paul, MN.

10. Johnson, T. E., and McManus, P. S. 1998. Inhibition of conidial germination and radial growth of Monilinia oxycocci by bacteria isolated from a cranberry marsh. Phytopathology 88:S45.

11. Köller, W. 1987. Isomers of sterol synthesis inhibitors: Fungicidal effects and plant growth regulator activities. Pestic. Sci. 18:129-147.

12. Köller, W., Parker, D. M., and Reynolds, K. L. 1991. Baseline sensitivities of Venturia inaequalis to sterol demethylation inhibitors. Plant Dis. 75:726-728.
13. Leroux, P., Gredt, M., and Boeda, P. 1988. Resistance to inhibitors of sterol biosynthesis in field isolates or laboratory strains of the eyespot pathogen Pseudocercosporella herpotrichoides. Pestic. Sci. 23:119-129.

14. Mahr, D. L., Roper, T. R., McManus, P. S., Hopen, H. J., and Flashinski, R. A. 1999. Cranberry pest management in Wisconsin. Univ. Wis. Ext. Publ. A3276.

15. McManus, P. S., Best, V. M., and Leininger, B. L. 1998. Reducing the risk of fungicide resistance in the cranberry cottonball pathogen, Monilinia oxycocci. Phytopathology 88:S61.

16. Oudemans, P., Caruso, F., McManus, P., Bristow, P., and Smith, J. 1997. 1997 National Cranberry Fungicide Screening Project Final Reports. Cranberry Institute, Wareham, MA.

17. Reynolds, K. L., Brenneman, T. B., and Bertrand, P. F. 1997. Sensitivity of Cladosporium caryigenum to propiconazole and fenbuconazole. Plant Dis. 81:163-166.

18. Sanderson, P. G., and Jeffers, S. N. 1989. The cottonball disease of cranberry in Wisconsin: Occurrence, symptoms, and disease progress. Acta Hortic. 241:312-317.

19. Sanderson, P. G., and Jeffers, S. N. 1992. Cranberry cottonball: Dispersal periods of primary and secondary inocula of Monilinia oxycocci, host susceptibility, and disease de- velopment. Phytopathology 82:384-392.

20. Schnabel, G., and Parisi, L. 1997. Sensitivity of Venturia inaequalis to five DMI fungicides, including the new triazole fluquinconazole, and to pyrimethanil. Pflanzenkrankh. Pflanzenschutz 104:36-46.

21. Shear, C. L., Stevens, N. E., and Bain, H. F. 1931. Fungous diseases of the cultivated cranberry. U.S. Dep. Agric. Tech. Bull. 258.

22. Sheridan, J. E., Grbavac, N., Sheridan, M. H., and Soteros, J. J. 1987. Further studies on triadimenol resistance in the barley net blotch pathogen Pyrenophora teres. N.Z. J. Agric. Res. 30:101-105.

23. Smith, F. D., Parker, D. M., and Köller, W. 1991. Sensitivity distribution of Venturia in aequalis to the sterol demethylation inhibito flusilazole: Baseline sensitivity and implications for resistance monitoring. Phytopathology 81:392-396.

24. Steel, R. G. D., and Torrie, J. H. 1980. Principles and Procedures of Statistics: A Biometrical Approach. 2nd ed. McGraw-Hill Book Co., New York. pp. 544-545.

25. Ypema, H. L., Ypema, M., and Gubler, W. D. 1997. Sensitivity of Uncinula necator to benomyl, triadimefon, myclobutanil, and fenarimol in California. Plant Dis. 81:293297. 